SHS Web of Conferences 10, 00035 (2014)

DOI: $10.1051 /$ shsconf/20141000035

C Owned by the authors, published by EDP Sciences, 2014

\title{
The responsibilities of extra familial care institutions' children as important personality characteristics development process
}

\author{
A. Razeva and K. Silova \\ University of Latvia, Latvia
}

\begin{abstract}
The questions about how and in which living activity areas the responsibility of extra familial care institutions' children as important personality characteristic is developed, in this paper are investigated. Responsibility category includes the problem of philosophy and sociology - the extent of which a person is able and can be the subject (the author) of his activity, as well as specific questions: the ability of the person knowingly (intentionally, voluntarily) to execute determined requirements and to perform specified tasks; to make certain choice; to achieve determined results, as well as to solve the issues. The concept of responsibility is described in various scientific papers. Executed empirical research creates the possibility to clarify the views of staff and children on the importance of responsibility and the possibilities of its development in extra familial care institutions.
\end{abstract}

\section{Introduction}

The main functions of extra familial care institutions are to provide a shelter, care for children and to ensure some kind of home and family for the students. Extra familial care institutions are provided for these children and young people who need compensation, continuation or addition of family upbringing because of different educational reasons (Eglīte B., 2002).

There are different types of child care and educational institutions or extra familial care institutions in Latvia, which provide social care for children depending on their age and health. In this paper, we analyze, how children's responsibility is developed when living in children's homes - in shelters, where social care is provided for orphans and for children who were left without parents care at age from 2 to 18 years (Ārpusǵimenes aprūpes un adopcijas sistēmas izpēte un ieteikumi tās pilnveidošanai, 2008).

Management and staff of extra familial care institutions are responsible for children from the moment when child is placed in the children home till the moment, when he leaves it, and often for some time afterwards - helping students to live without assistance, coordinating with biological families and guardians. During placement of the child in extra familial institution, it is necessary to provide all conditions and opportunities for successful socialization of the child.

This is an Open Access article distributed under the terms of the Creative Commons Attribution License 4.0, which permits unrestricted use, distribution, and reproduction in any medium, provided the original work is properly cited. 


\section{SHS Web of Conferences}

Table 1. Reasons for placing children in social care institutions* (at the end of the year).

\begin{tabular}{|l|l|l|l|l|l|l|}
\hline & \multicolumn{9}{|l|}{} & \multicolumn{3}{l|}{$\begin{array}{l}\text { Social care centres of local } \\
\text { governments and other } \\
\end{array}$} & \multicolumn{2}{|c|}{ State social care centres } \\
& organisations \\
\cline { 2 - 8 } & 2005 & 2010 & 2011 & 2005 & 2010 & 2011 \\
\hline Total number af children & $\mathbf{8 4 1}$ & $\mathbf{6 0 2}$ & $\mathbf{5 8 5}$ & $\mathbf{2 0 4 0}$ & $\mathbf{1 2 6 8}$ & $\mathbf{1 3 6 5}$ \\
\hline orphans & 6 & 12 & 11 & 164 & 57 & 65 \\
\hline children left without parental care & 835 & 590 & 574 & 1876 & 1211 & 1300 \\
\hline $\begin{array}{l}\text { child care rights terminated by orphans } \\
\text { court judgment }\end{array}$ & 202 & 280 & 261 & 789 & 535 & 616 \\
\hline custody rights terminated by court judgment & 57 & 119 & 130 & 928 & 651 & 652 \\
\hline other reasons & 576 & 191 & 183 & 159 & 25 & 32 \\
\hline
\end{tabular}

*(Bērni Latvijā 2012).

\section{Responsibility and its characterization}

Attaining their majority, young people are standing on the threshold of independent live, but they do not feel ready. On the one hand, they want to live independently, to be independent, but on the other hand they are afraid of it. It is difficult for young people to be responsible and independent, because their previous life experience in the family and the socialization process has not been successful.

Extra familial care institutions' children stay behind their peers in social development. These young people are dependent on others, they are not sure about relationship development, and their identity is based on the idea of their own, rather than the personality, considers the psychologist V. Mukhina. Young people have no possibility to be alone in children home. Children have no close contacts with adults in children home. Extra familial care institutions' children do not develop the ideas about the character and social roles (Мухина В., 2005).

Education is very important in development of young people's responsibility and independence. The first important point in Latvian education system is elementary education. The task is to provide an opportunity to prepare for independent life, to help children and teens to obtain basic knowledge and basic skills for life (Valbis J., 2005).

Extra familial care institutions' children have a specific attitude towards school. The authors' experience shows that many extra familial care institutions' children are not motivated enough to learn, others do not want to continue their education after elementary school, and others do not want to work. Many extra familial care institutions' students do not acquire behavior norms, are not able to make decisions and do not take responsibility for their own actions and their consequences.

The responsibility is defined in different ways, however it has common characteristics that appear in all definitions.

Philosophers define "responsibility" as ethical and legal category that reflects the personality of special social and moral legal attitude towards society, attitude, which characterizes the execution of moral and legal obligations (Aizenšteins V., Rozentāls M. et al., 1974).

Whereas, in the context of ethics, the responsibility (moral) is explained as ethical category that describes the personality depending on how a person executes its obligations, moral requirements, determines the rate of participation of a person and social in their own moral development, as well as in the process of public relations improvement. Responsibility is the compliance of person's moral action to his obligations, which are considered from the view of person's opportunities. It is person's ability to execute his obligations (Kons I. et al., 1987).

In pedagogy, responsibility has been described as attitude, which is characterized by cognition of obligation; identified necessity to be responsible for their actions and their consequences, to execute 


\section{Int. Conf. SOCIETY. HEALTH. WELFARE.}

the tasks that are specified in society. Cognition of responsibility among students is executed during the pedagogical process. The more public authorities and real opportunities of a person are, the higher his level of responsibility is. Cognition of responsibility is developed by the teacher due to his attitude towards work, learning process, obligations (Blūma D., Skujiņa V. et al., 2000).

The psychologists emphasize the responsibility as the obligation of person or entities, the necessity of self-control, taking care of their business processes and consequences (Breslavs G. et al. 1999).

Responsibility category includes the problem of philosophy and sociology - the extent of which a person is able and can be the subject (the author) of his activity, as well as specific questions like the ability of the person knowingly (intentionally, voluntarily) to execute determined requirements and to perform specified tasks; to make certain choice; to achieve determined results, as well as to solve the issues. (Aizenšteins V., Rozentāls M. et al., 1974) Responsibility is an external, objective necessity that turns into internal stimuli, self-activity, respect to obligations (Lasmane S., Milts A., Rubenis A., 1993, p. 93).

Responsibility is formed gradually, for a long time. The child will not become the responsible person due to successful education. Responsibility may require both the psychological and social responsibility characteristics. Psychology determines four stages for the responsibility determination:

- In the first stage, a readiness to be responsible for positive sequences, to receive gratitude, consent, but do not be responsible for negative consequences of an actions is shown;

- In the second stage or level, pronounced conformity, when a person recognizes common fault of the group, but refuses the personal responsibility if it does not recognized by the group is shown;

- In the third level, the responsibility subject is created, self-activity and activity of the group is evaluated more critically, in some cases recognizing both the group's and its own mistakes, fault, feeling regret for bad done;

- The fourth stage is "I am responsible", when the responsibility is related to the person's characteristics, values, beliefs - the person compares them with his behavior. At this stage the person more impacts on the environment than the environment impacts on the person. Positive action is possible in terms of non-control and non-monitoring. (Lasmane S., Milts A., Rubenis A., 1993, p-93).

In social characterization, the responsibility is divided into 3 levels - irresponsibility, shallow and deep responsibility.

Irresponsibility is related to a personality that is able to be responsible for its actions. Irresponsibility also is supported by declarative, formal requirements, when in advance is expected that declarative, formal accountability will be. Irresponsibility develops the illusion of freedom, but in reality it puts a person in a boat of recession that goes to the first rapids (Lasmane S., Milts A., Rubenis A., 1993, p-93).

Shallow responsibility is close to the concept of heteronomous responsibility that is used in research literature, when a person mainly is the responsibility subject, and responsibility depend on external factors - fear of punishment, opinion of the group and society. However, the shallow responsibility shows the person's inner unpreparedness, insufficient self-education, and moral poverty. Shallow responsibility includes the report only for present. A person is not responsible for his words, actions in future, is not responsible for words and actions in past. Both irresponsible and shallow responsibility in different areas can be shown differently, often turning into each other. Irresponsibility for the development of the blocked paths of conscience, but shallow responsibility distorts the conscience (Lasmane S., Milts A., Rubenis A., 1993, p-94).

Deep responsibility is formed during life, making social important obligation as personal obligation, making closer responsibility and self-esteem, sense of life, conscience. This responsibility also is known as autonomous, real responsibility. It is sovereign, independent, competent responsibility of 


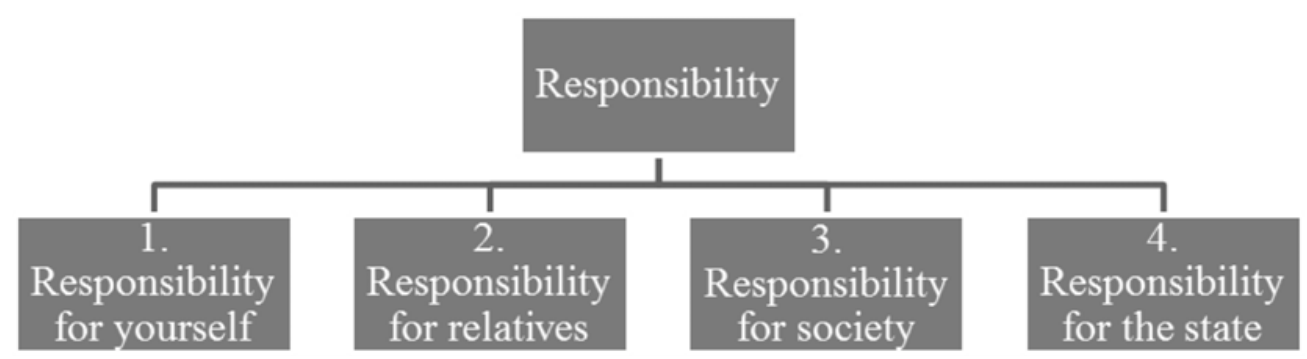

Figure 1. The structure of responsibility.

the person. Because obligation becomes an internal factor, deep responsibility significantly affects the internal world, making it possible to distinguish better the real obligations and formal obligations. Deep responsibility is the responsibility for final result (Lasmane S., Milts A., Rubenis A., 1993, p-94).

The author believes that the responsibility of the child is formed during education process, starts during the first games at home, continues in pre-elementary education institution and communication at home, explaining to a child the importance of responsibility and help them to understand the nature, at first learning in games - later from their own experience.

If a child is prepared to learn at school and if he develops his cognitive skills, it is very important for pre-school children to develop social - emotional skills, it helps the child to be more successful in appropriate society. It includes cooperation with other children and adults, self-control, as well as to be responsible in various social situations. The first years of life is ideal time for parents and guardians to start to teach the children to be responsible in accordance with their age (Andersone R., 2004).

\section{Responsibility for yourself}

Personal acceptance of responsibility includes:

- responsibility for own life, about what to tell, to feel, to choose;

- to protect and promote the health and emotional prosperity;

- to develop yourself positively, self-assertion, self-regulation (Gonzalez - Mena J., 2009).

\section{Responsibility for relatives}

One of the ways how to teach the children the responsibility is to tell them about your worries. For example, to involve the children regularly in works around the house, take care and provide the order at home. The order at home has to be learning for children from the child's first steps, the child has to pick up his toys after games, thus promoting the responsibility in the child. If parents protect their children and take care about them too much, not allowing a child to act independently, such activities do not promote the development of the child's responsibility. If parents allow the child to do everything he wants, the child may become irresponsible (Андреева А., Гудкина Н., 1999).

\section{For society (school, village, town)}

Every education institution, extra familial care institution has internal order handling rules, which specify the students' responsibility and penalties due to non-observance of these rules. A person 
Int. Conf. SOCIETY. HEALTH. WELFARE.

Table 2. Age of the students who participated in questionnaire.

\begin{tabular}{|l|l|l|}
\hline Age of the youngsters & $\begin{array}{l}\text { Respondents number at each age } \\
\text { group of RPBJC “A” }\end{array}$ & $\begin{array}{l}\text { Respondents number at each } \\
\text { age group of "Dzivespriek } \bar{a} \text { " }\end{array}$ \\
\hline 15 years & 3 & 3 \\
\hline 16 years & 6 & 6 \\
\hline 17 years & 3 & 6 \\
\hline 18 years & 1 & 3 \\
\hline 19 years & 1 & - \\
\hline 20 years & - & 1 \\
\hline Total & 14 & 19 \\
\hline
\end{tabular}

develops his trust only by trusting. It is important to provide an opportunity for the students to be independent and responsible - I am responsible for my actions, I am responsible for the fact that not only me, but also my friend feel safe and free. If everyone always and everywhere observed this principle, we would not have the reason not to trust. Not only parents or teachers are responsible for the order, for safety at home and office, but also each child keeps this responsibility (Андреева А., Гудкина Н., 1999).

\section{Responsibility for the state}

Children's responsibility for the violation of the law is specified in the Children's Rights Protection Law (Chapter 9, Children's responsibility for the violation of the law and its prevention) (Ceplis D., Vilks A. et al. 2001). In the laws, the importance of responsibility is determined. In the Children's Rights Protection Law the responsibility norms for the children are determined. This law also regulates the basic conditions in accordance with which the child's behavior is controlled and his responsibility is determined, it regulates the right, obligations and responsibility of the parents and other individuals and legal entities, as well as state and municipality, determines the child protection system and legal principles of its execution.

Whereas the UN Convention on the Children's Rights also determines the children's responsibility. The Convention, Article 31 determines that children have to have an opportunity for development and social education in order they could develop different social skills, including responsibility skills (ANO Konvencija par bērnu tiesībām).

\section{Materials and methods}

The research was performed in Riga Municipal Children and Youth Centre Structural unit "A" and in Aizupe, Kandava district, Association "Dzivvesprieks". One of the data obtaining methods in this research was a questionnaire - 2 different questionnaires were used. The first questionnaire helps to determine the employees' opinion about the meaning of responsibility for the starting of independent life. The employees' questionnaires were developed by including unstructured questions or free-form questions. Processing of the obtained results was performed by content analysis method. The second questionnaire helps to determine the youngsters' opinion about the development of responsibility and an understanding of its importance. The second method of data obtaining was the analysis of the documents that are included in the case. In this article, just the information obtained through the analysis of documents included in youngsters' personal files, as well as through questionnaires is analysed. 


\section{SHS Web of Conferences}

Table 3. Youngsters' opinions about their responsibility.

\begin{tabular}{|c|c|c|c|}
\hline Aspects & Youngsters' answers & $\begin{array}{l}\text { "Dzīvesprieks" } \\
\text { respondents } \\
\text { number }\end{array}$ & $\begin{array}{l}\text { structural unit } \\
\text { " } A \text { " respondents } \\
\text { number }\end{array}$ \\
\hline \multirow[t]{6}{*}{$\begin{array}{l}\text { Responsibility for } \\
\text { actions }\end{array}$} & $\begin{array}{l}\text { To think about their activities, to be able to } \\
\text { predicate the consequences of own activities }\end{array}$ & 8 & 3 \\
\hline & To observe own words and activities & - & 2 \\
\hline & To understand the reasons of own activities & 1 & - \\
\hline & $\begin{array}{l}\text { Do not take credit at the bank, if you can not } \\
\text { to return it }\end{array}$ & - & 1 \\
\hline & $\begin{array}{l}\text { To undertake execution of tasks which you can } \\
\text { execute }\end{array}$ & 1 & 1 \\
\hline & To execute a task without assistance. & 1 & - \\
\hline \multirow[t]{3}{*}{$\begin{array}{l}\text { Responsibility for } \\
\text { people around }\end{array}$} & $\begin{array}{l}\text { To take care about everything you are related } \\
\text { to }\end{array}$ & 1 & - \\
\hline & $\begin{array}{l}\text { To take care about safety of yourself and } \\
\text { others }\end{array}$ & - & 1 \\
\hline & To take about yourself, relatives and others & 5 & 3 \\
\hline \multirow[t]{5}{*}{ Other answers } & To behave in society accordingly & - & 1 \\
\hline & $\begin{array}{l}\text { To live in accordance with conscience, to } \\
\text { fulfill your obligations in accordance with } \\
\text { conscience }\end{array}$ & 1 & 1 \\
\hline & $\begin{array}{l}\text { To fulfill your obligations in accordance with } \\
\text { conscience }\end{array}$ & & \\
\hline & $\begin{array}{l}\text { Internal feeling that appear because of impact } \\
\text { of obligations }\end{array}$ & - & 1 \\
\hline & No answer & 1 & - \\
\hline
\end{tabular}

\section{Results}

Performing the analysis $(n=14)$ of the functional capacity in the context of responsibility of students in Riga's Municipality's Children and Youth Centre structural unit "A", it is possible to conclude that:

1. Youngsters with responsibility take care of their appearance and clothing that is characteristic for adolescents;

2. Understand the importance of cleaning the premises and maintaining order, but rarely anyone does it, difficulties to motivate themselves for the job have 10 out of 14 youngsters. Responsibility for the cleanliness of the premises is the one youngsters do not want to undertake; this means that they clean the room when the teachers indicate it;

3. There is an understanding about health and its importance, but part of youngsters have difficulties to take care of their own health, it means that youngsters are not capable to take responsibility for their health; they dress inappropriate for the weather, use unhealthy food, smoke, recklessly consume medications, etc.;

4. Youngsters have difficulties to comply with the daily regime, as well as to observe the safety on the street, and their response according to the situation is inadequate. This shows the lack of responsibility, because of risking withtheir own health and life without thinking about the consequences;

5. The difficulty arises also because of failure to recognize and fulfill the rights and obligations, only half of all youngsters accommodate with this sucessfully; 9 out of 14 youngsters also have difficulties to recognize the action and its consequences. 


\section{Int. Conf. SOCIETY. HEALTH. WELFARE.}

6. Use of money and shopping cause difficulties to 12 out of 14 youngsters, most of the youngsters are not able to use their money rationally, this shows a lack of responsibility, because the ability to make good use of their allowance can be helpful to the youngsters later in life;

7. Behaviour presents a problem for 6 of the 14 youngsters, inappropriate reaction and inability to control themselves and acting recklessly refers to youngsters' lack of responsibility.

8. Working skills are giving difficulties to 10 out of 14 youngsters, the most difficult for young people is to accept criticism and correct errors, as well as the ability to plan and do sequence tasks. This information indicates that young people need to bring order into their inner world to be able to adequately perceive criticism and responsibly perform their duties.

Performing the analysis $(n=14)$ of the functional capacity in the context of youngsters responsibility in the Association "Dzivesprieks", is possible to conclude that:

1. All young people responsibly treat the responsibilities mentioned in the rules of internal order. According to the on-call schedule in kitchen they prepare meals, make and clean the table, serve others at the table. Responsible attitude is also stimulated by the fact that the above-mentioned skills are developed for all "Dzivesprieks" youngsters as part of the teaching curriculum.

2. Youngsters behave responsibly and according the situation with the right choice of clothing. This could be due to the activity in the kitchen where it is necessary to comply with health and hygiene standards, as well as the fact that guests are taken on a regular basis.

3. Cleaning and maintenance of the premises is not a problem for any of the youngsters. It is possible because in the institution on a daily basis chooses a responsible person who checks both the public areas and rooms. Consequently, youngsters have the necessity to take care of the cleanliness of the premises. But if there wasn't a person on duty, only then it could be possible to clearly detect what is the attitude and the ability of the youngsters to maintain the premises. The author believes that this on the one hand promotes responsibility, as each day one youngster is ordered to check the cleanliness of the premises, but on the other hand, it partially breaks the development of responsibility, because person is forced to do so, instead of doing do it by his own initiative to keep the premises in order.

4. 7 out of 19 youngsters have difficulties to take care of their health. A passion for smoking, alcohol, etc. substances is posing health problems to students. It also indicates that youngsters' responsibility for their own health is low. Young people do not realize the importance of health, and they are able to act irresponsibly, experimenting with a variety of addictive substances.

5. Difficulties in mobility, orientation skills, understanding of safety have 5 out of 19 youngsters. The most difficult things for young people is to follow fire safety and road safety rules. Responsibilities for their own and for other young people lives still have to be learned to undertake.

6. Self-awareness, or awareness of their strengths and weaknesses, awareness of the consequences of their actions, and awareness of the rights and obligations arise difficulties in 10 of 19 young people. This indicates a lack of responsibility of young people.

7. Regarding the use of money and shopping, - 12 of the 19 "Dzivesprieks" youngsters have difficulty with the rational use of money. Youngsters still have to learn the responsibility for dealing with money. Little has been done in practice, it is only theoretical knowledge of finance, as youngsters live in a rural area and the closest store is several miles away, they are not experienced in actions that other youngsters take on a daily basis.

8. Communication skills arise difficulties in 5 of 19 youngsters. The most difficult for young people is to solve a conflict by themselves, it is probably a result of the nature of adolescents, the youngster cannot or do not want to understand other people's point of view and do not know how to express his own one, and it results in failure of the two parties to reach a compromise. 


\section{SHS Web of Conferences}

This indicates that the student still has to learn to come to terms with him or herself to be able to become more responsible and more independent in certain life situations.

9. 3 of the 19 youngsters have difficulties to behave according to the social situation, to engage in dialogue and to refrain from interfering in other conversations. However, these particular students do not have problem to follow basic urbanity, such as greeting, thanking, addressing in, this indicates that students are familiar with responsibility but it is difficult to control their emotions.

10. In the work area, difficulties are expressed in 4 out of 19 youngsters. Two of the youngsters had specific difficulties to fulfill their tasks with responsibility; it shows a lack of responsibility on the youngsters' particular area. 1 youngster has difficulty maintaining order in its job, it might be due to personal characteristics, backgrounds, or entering into the activity without noticing what is going on. Another youngster has difficulty to accept criticism and correct his mistakes; it might be that youngster perceives protests personally which disrupts reacting to it adequately. Performing evaluation of the youngsters' individual development plan, the author evaluated what is being done to encourage positive youngster responsibility. Performing the examination of this document, it was found, that a specific, targeted actions in different areas contribute to students' autonomy (autonomy - the ability, in terms of freedom of opinion, independence of thought and action of others, other opinions, orders, impact) and independence (independence the ability to act as they wish, without the intervention of another person), but no indication of responsibility.

The areas, in which establishing goals and objectives contribute to improve youngsters' autonomy and independence, are:

- Intellectual development, job training;

- Physical development;

- Abilities, interests and talents, extracurricular work;

- Social development, communication, behavior, autonomy;

- Relationship with the biological family;

In none of the specified fields, responsibility as an important feature for youngsters in starting an independent life is highlighted.

By summarizing the results it can be concluded that a number of youngsters have similar difficulties in similar areas. To summarize the objectives set out in individual development plans, the author concluded that the individual development plans are aimed at the development of a particular activity, but not to the development's characteristics. It is possible that through the activities are designed to develop also the characteristics, but no goals or tasks that are not disclosed in writing.

The author concludes that youngsters are motivated, encouraged for wide variety of actions, and selfdevelopment, nursing, teaching, disciplining and improving interaction and communication with others. Is also provided independent operation of taking the initiative, it means the responsibility of the specific activities. It can be concluded that an individual rehabilitation plan does not work as a rehabilitation plan only by itself because rehabilitation includes restoring skills, abilities, which for have been lost for some reasons, they are renewed in the rehabilitation process. This document is more likely to be a personal development plan.

\section{Discussion}

Responsibility as one of the most important personal characteristics has acquired wide reflection in theoretical works of significant educators, philosophers, psychologists of this century, as well as in past centuries, and it is very significant in social psychological practice. Responsibility can be described as an attitude, which is characterized by a sense of duty, intentional need to answer for own actions 


\section{Int. Conf. SOCIETY. HEALTH. WELFARE.}

and its consequences, to undertake and fulfil the challenges of society. The child who has grown up in a family after always able to get the support of parents, however, the youngsters of children's homes don't have the possibility to have this kind of emotional connection. A study about promotion the responsibility of youngsters from non-family care institutions shows that youngsters from home care institutions are partially detached from the domestic developments; in orphanage, it is not always is possible to acquire the skills to function independently in society, take responsibility for yourself, your life, your surroundings. Therefore, the responsibility as a personality characteristic is very important and its development must be promoted with the professional competence of employees. The empirical data from the study indicates the need to optimize the environment of social centre and to bring activities of youngsters maximally close to family-like environment.

\section{Conclusions}

- Responsibility is an important personality characteristic for any young person, but it is particularly important to encourage the development of these qualities for young people living in children's homes, because they, starting the independent life, most likely will rely solely on its own merits;

- During the research, the author concluded that the development of the responsibility of youngsters from non-family home care institutions has been little studied. There is not extraction and gathering of information about former youngsters' further life and therefore it fails to clarify what exactly are the biggest obstacles of development of the responsibility for these young people non-family home care facilities and what is the level of responsibility of youngsters starting an independent life.

- Lack of emotional intimacy prevents the development of youngsters at all levels and therefore the responsibility as characteristic does not develop, they haven't felt others responsibility for them.

- Young people who live non - family home care often are having more theoretical knowledge (ideas) than practical skills about an independent life. Young people have low level of responsibility, or even the lack of it because the activities the young people are involved may not always promote responsibility. Funds which are allocated to home care institutions are limited and they prevent the full use of every opportunity to promote independent living skills and abilities and also the possibilities of developing the responsibility are limited. Youngsters are not being taught to plan and organize their budget because they do not have the any opportunities to earn money, therefore they do not understand its value and do not know how to handle it responsibly.

\section{References}

[1] Aizenšteins V., Rozentāls M. et al., (1974) Filozofijas vārdnīca, Rīga: Liesma.

[2] Blūma D., Skujiņa V. et al., (2000) Pedagoǵijas terminu skaidrojošā vārdnīca, Rīga: Zvaigzne $\mathrm{ABC}$

[3] Breslavs G. et al. (1999) Psihologiijas vārdnīca, SIA Mācību grāmata.

[4] Ceplis D., Vilks A. et al. (2001) Bērns un kriminalitāte, Raka, Rīga.

[5] Eglīte B. (2002) Atstumtie bērni Latvijā: problēmas un to risinājumi, Rīga: Zvaigzne ABC.

[6] Kons I. et al. (1987) Ėtikas vārdnīca, Rīga: Avots.

[7] Lasmane S., Milts A., Rubenis A., (1993) Ėtika, Rīga: Zvaigzne ABC.

[8] Andersone R., (2004) Pusaudžu sociālo prasmju veidošanās, Rīga: Raka.

[9] Valbis J. (2005) Skolēna personības attīstība-izglītības virsuzdevums, Rīga: Zvaigzne ABC.

[10] Gonzalez - Mena J. (2009) Child, family and community, Upper Saddle River.

[11] Андреева А., Гудкина Н. (1999) Формирование личности старшеклассника, Москва: "Академия". 
SHS Web of Conferences

[12] Мухина В. (2005) Возрастная психология: феноменология развития, детство, отрочество, Москва: Академия.

[13] ANO Konvencija par bērnu ties̄̄bām [tiešsaiste] pieejams internetā http://www.humanrights. lv/doc/vispaar/bernkonv.htm [atsauce 07.05.2013].

[14] Ārpusǵgimenes aprūpes (ārpusǵgimenes aprūpes iestādes, audžuǵimenes, aizbildnība) un adopcijas sistēmas izpēte un ieteikumi tās pilnveidošanai, 2008, Pētījuma gala ziņojums, Rīga, SIA "Analītisko pētījumu un stratēgiju laboratorija" pēc LR bērnu un ǵimenes lietu ministrijas pasūtījuma, 295 lpp., [tiešsaiste] pieejams internetā: http://www.bm.gov.lv/lat/informacija_ jums/petijumi/?doc $=11314$ [atsauce 04.05.2013.].

[15] Bērni Latvijā 2012, Statistisko datu krājums, LR Centrālā statistikas pārvalde, Rīga, 2012. 